\title{
Research on the Sino-us Trade Conflict and Countermeasures
}

\author{
Qige Wu \\ School of economics, Tianjin polytechnic university \\ E-mail:jinzairan888@163.com
}

\begin{abstract}
With the development of information and science \& technology, the pace of globalization is accelerating, which has more and more great influences on international trade. The development of economic globalization not only deepens mutual interdependence among countries, but also raises their conflicts and frictions. Trade conflicts will affect the development of bilateral trade and regional economy, which may result in worldwide economic crisis. Because of the development of foreign trade and rise of Chinese economy, there are more and more conflicts between China and its trade partners, especially Sino-US trade conflicts. In today's increasingly competitive world economy, international competition is no longer just the capital and technology competition Law has been involved in the game. China should learn to use the weapon of law and other ways to protect themselves.
\end{abstract}

Keywords: Sino-US trade, Trade conflicts, Trade imbalance, Influence on China's economy and trade, Countermeasures research

\section{The status of Sino-US trade friction}

Since China implemented the policy of reform and opening-up in the 1970s, economic cooperation and trade relations between China and the United States have made considerable progress. China and The United States, as the largest developing country and the most developed country, have been important trade partners in trade and investment, which play a decisive role in promoting the process of economic globalization and trade liberalization. Due to the rapid growth of Sino-US trade and worsening of trade imbalance, bilateral trade conflicts become more and more intense.

\subsection{Trade friction has been involved in every field}

Since China's accession to WTO, Sino-US trade conflicts have gradually risen from micro-economic to macro-economic field. The number of China's exports has reached more than 4000 . These products transferred from the original agricultural products, including chemical raw materials, textiles to the steel, color television, telecommunications which are capital-intensive and technology-intensive manufactured goods. With the opening of goods and service market as well as the upgrading of industrial structure, New industries and products become the subject of trade friction, For the reason that Sino-US trade conflicts will take on the features of continuance, frequency and complication.

\subsection{China faces the main form of trade friction which contains Anti-dumping, special safeguard measures.}

As we all known, Since 2007, As Chinese economic has been developed more and more quickly, the United States began to use different ways and means to cause an even greater pressure on China to achieve its own economic and political purposes, because the United States worried about China's economy growth, including Anti-dumping, the appreciation of RMB and so on. To Chinese Products, U.S. has been taking more and more measures such as anti-dumping, anti-subsidy, and peculiar safeguard measures, which is a serious distortion of free trade. According to the traditional international economical theory, any distortion of free trade will do harm to trade-country's social welfare level, and cause "deadweight loss" to the whole world, and is also not in accordance with the symptomatic rules". There is no doubt that the growing trade conflicts is putting increasingly negative impacts on the smooth development of Sino-US economic and trade relations. This phenomenon has aroused interests of many people, and so how to view this and how to deal with it become the major issue of common concern for China's government, business and academia. In face of the increasingly fierce trend of Sino-US trade conflicts, how to resolve Sino-US trade conflicts has been a major issue in China's economic development and foreign trade, which is also of great value to dealing with trade conflicts between developed countries and developing countries.

\subsection{Technical Barriers have badly affected our exports.}

China is the world's largest developing country, the level of economic development is not high and the overall quality of export products is lower. The export market for our products mainly concentrated in the developed countries and some newly industrializing countries, trade volume reached more than $90 \%$, but now these countries become more and more strictly with import products, Export products made in China will inevitably face a growing number of technical barriers. 
1.4 Balance of trade, the RMB exchange rate, intellectual property protection and labor standards cause trade frictions.

\section{The original causes of Sino-US trade friction}

\subsection{The external background of Sino-US trade friction}

Economic globalization is an irreversible trend in the development of modern economic. Under the impetus of globalization, it deeps the economic links between countries and strengthen the interdependence. At the same time, the opportunity of the economic friction between countries has been greatly increased. Production of global and unified world market requires the convergence of the system, rules and even the culture and customs. However, domestic regulation has seriously affected the development of the economic and trade among nations. And some countries existed differences in social systems, historical backgrounds, consumer preferences, can not achieve full integration in a short period of time, As long as these differences exist, trade friction between countries is inevitable. Sino-US trade has a highly complementary, In theory, China's exports to the United States should have a comparative advantage in labor-intensive products, U.S. export the capital and technology-intensive products, but in the reality, for the purpose of containing China, The United States did not export capital and technology-intensive products, and it restrict exports on high-tech. therefore it result continuing large trade deficit. The United States that is on grounds of serious trade imbalance launch trade friction to China.,Increasing the Sino-US trade friction has been generated.

\subsection{Internal root causes of Sino-US trade friction}

China and the United States are very important trade partners, the two countries have highly complementary in the market, resources, technology, capital and other areas. At present, China is America's fourth largest trading partner, while the United States is China's second largest trading partner.

\subsubsection{From the Chinese point of view}

Firstly, the rising of Chinese economic. Since the policy of reform and opening up, Chinese economic development is remarkable. China has become the second largest economic power in the world, If the current trend developed, in the 21 st century before the end of the first 10 years is likely to catch up with Germany, during the second 10 years, China may be second to the United States, Japan, the European economic power. China's status as a world trading power has also increased rapidly, for example, China's trade volume to the United States reached 211.6 billion U.S. dollars. Trade surplus volume is up to 114 billion U.S. dollars and China became the largest exporting country to the US. The United States economy has been declined in this years, while China's economy has maintained a sustained high growth, it result to Sino-US trade friction. Secondly, Dependence on trade with the United States is too large. Since reform and opening up, foreign trade in China's national economic play an important role in development process of national economics. Thirdly, the structure of export is lower, Labor-intensive products exports occupy a dominant position in the structure of Chinese export products, these products include textiles, clothing, shoes, toys, bags, etc. These industries are often at a low level, low technology, less innovation capability, alternative products, easily to reduce the market share of Chinese products. Once Chinese exports to the United States increased dramatically, causing the U.S. trade deficit, the United States will take various measures to restrict imports of our country, the occurrence of trade friction is inevitable. Last but not the least important, Enterprises Lack self-discipline and export disordered. In recent years, the quantity of export products increased dramatically, but the volume of trade isn't increasing. This is mainly because the domestic enterprises which have to compete for the market shares have an image of "small profits but quick turnover". In addition, foreign trade enterprises are subsidied by our own country at a long-term. As a result, many foreign trade enterprises complete the export targets and compete for market fixed lower price, Thus they often have been accused by dumping. Some enterprises which in order to obtain export subsidies and export tax rebate sale products without profits, the results for the United States has accused China and launched a trade war against China, finally it would hurt China's enterprises.

\subsubsection{From the united states point of view:}

In the first place, In order to achieve the so-called "fair trade", U.S. foreign trade policy has obvious characteristics of the two sides, one is that the US promote the liberalization of export trade, the other is the United States insists on import trade protectionism. Under the guidance of this policy, As long as the economic is in deep recession or the United States enhance domestic trade protectionism, it will lead to trade friction between United States and other countries. In the second place, US adopt the policy of restrict export, Sino-US trade imbalance is one important reason for the trade friction, The United States does not only seek nothing of its own reasons, but also attribute a large number of trade deficit to the exports from China to the US. Actually, there are many factors constraint Sino-US trade, for instance, Differences in trade statistics, Restrictions on exports to the United States and so on, Restrictions on U.S. exports is an most important factor that other factors can not be compared with .In the third place, the US restrict commodities which are made in China, because America worried about the Chinese sustained and rapid economic development, The United States does not want to see such a country whose economic is growing better and better. Therefore, anti-China forces in the United States regarded China as a potential enemy. The current Sino-US trade 
friction is not accidental, it is not only tactical, but also inevitable and strategic. China's rising is so quick that U.S. government is bound to take a series of measures to try to contain this development. Sino-US trade friction will occur frequently. Last but not the least important, for the needs of U.S. domestic politics, Politic and economic are closely and inseparable, although the trade frictions performed in the economic field, but in fact there is a profound political reasons. In order to win election victory every four years, U.S. politicians have to yield to special interest groups. They always make a fuss about policy to China, only in this way can they obtain valuable votes, because the political survival rules of the United States is that candidates must get more votes.

\section{How to deal with the Sino-US trade friction}

Faced with the increasing competition in the Sino-US trade friction, we need to face up to it in ideology and value in strategic as well as look down up in tactic.

\subsection{Consideration from the government level}

The Government should treat Sino-US trade friction calmly and take appropriate diplomatically strategy and tactics. So it is safe to say that China's rise is a peaceful rise, the rise of China will more vigorously promote world peace and development; it emphasized trade is mutually beneficial, "win-win". Flexible diplomatic strategy can greatly increase the ability to resolve trade friction. What's more, The Chinese government should be familiar with US deeply and exhaustively in every aspect, such as political, economic, social and cultural. In order to protect their own interests, China must learn to recognize and think problems which happened between China and the United States by standing on the point of view of our partners, put forward trade policy and operational skills. China should follow the economical mode of major countries, regard domestic demand as the main engine of the development and adjust the proportion of domestic demand and foreign demand. Our government also should Change the growth mode of foreign trade, only in this way, we may keep the macroeconomic develop rapidly. In addition to the above, on the one hand, In order to solve Sino-US trade friction, Chinese Government should strengthen communication with the United States Government and gradually establish regular bilateral consultations and coordinate mechanisms, discuss economical cooperation regularly, eliminate the differences which is happening between US and China in international economic policies, maintain the stable development of Sino-US bilateral economical and trade relations. On the other hand, WTO dispute settlement mechanism that is used by all over the world especially developing countries is an effective ways to resolve trade conflicts and protect their own legitimate rights.

\section{2 consideration from the enterprise and industry level}

Enterprises at all levels must develop products by competing procedure of manufacture which is high-tech and high-value, do a good job for the development of major export products, convert the business mechanism for enterprise, establish a modern enterprise system, attract excellent person, implement strategy which is priority of quality, learn how to use trademarks, packaging, public relations, advertisement and other means of non-price competition, explore actively new overseas markets, bring up the advantage of competition. Finally, as a non-market economy country, we should learn to deal with anti-dumping from other countries especially developed countries. What's more, high-tech products are increasingly becoming the major kinds of world trade and coupled with a serious oversupply of labor-intensive products in international market, so competition gradually decreased. Our enterprise wouldn't rely on the labor-intensive products to obtain profits, we should changed from labor-intense to tech-intense, realized diversity of export products, we should also adjust regional structure of export, expand from traditional Asia and North American to Latin America, the Middle East and African markets, so we can reduce the risk of trade friction. It is safe to say, our government should also promote enterprises to go abroad actively, the corresponding volume of exports is bound to decrease, this will certainly alleviate trade friction. In additionally, with the change of functions, the government will not resolve trade dispute, while the strength of individual enterprise is limited, therefore, industry association have a unique advantage for prevention and settlement of trade disputes. Industry associations should join the government and enterprises to build trade early warning mechanism.

\subsection{Resolving trade friction by means of interest relation.}

In modern times, A universally truth is to be said as following: There is no permanent enemies and friends, nothing is more important than eternal interests for the business company. In recent years, Many US multinational companies have substantial operations in China, so that they can take advantage of Chinese cheaper labor resources. The US companies have always attached importance to the great trade interests with China, So China has the opportunity to make use of these economic resources and political resources.

\section{Concluding remarks}

China has emphasized for several times not to politicize economic problems but this is only its own wishful thinking. Trade collisions are the products of foreign trade at a certain period of time and it is restricted by political factors. If we can address the mutual benefits and the collisions of Sino American trade properly, it is not possible for the collisions to become trade wars in the international trade where benefit is the name of the game. The comparative advantage of 
benefit over collision determines that the mutual trade relationship of the two countries will continue to develop.

\section{References}

Ludema, Rodney D. Wooten. (2001). June, 355 - 376. Good Optimal international trade agreements and dispute settlement procedures European, Journal of Political Economy Volume: 17, Issue:2.

Rowbotham, E. (1995). July,291.The changing nature of dispute settlement under the GATT and the WTO Fuel and Energy Abstracts Volume: 36, Issue: 4.

Bown, Chad P. March. (2004). 263 - 294. Trade disputes and the implementation of protection under the GATT: an empirical assessment Journal of International Economics Volume: 62, Issue: 2.

Jim Perlow. "Trade Deficit with China Puts US at Disadvantage". http://Phoenix.bizjouranals.eoln/Phoenix/stories/2002/10/140editorial4.html.

(2005). Report to Congress of the U.S. China Economic and Security Review commission, http://www.usee.gov/researehPaPers/annual-rePorts.htm/httP://www.sei.sn.cn.

Bown, Chadp. Rachel McCulloch. (2005). U.S. Trade police Toward China; Discrimination and Its Implication. 